\title{
CURRENT ISSUES OF LEGAL REGULATION OF SURROGATE MATERNITY AND ENFORCEMENT OF RIGHTS OF SURROGATE MOTHERS
}

DOI: 10.36740/WLek202012228

\author{
Oksana P. Kuchynska' ${ }^{1}, 0$ ksana Yu. Kashyntseva ${ }^{2}$, Oleh V. Shchyhol ${ }^{3}$ \\ 'INSTITUTE OF LAW OF TARAS SHEVCHENKO NATIONAL UNIVERSITY OF KYIV, UKRAINE \\ ${ }^{2}$ CENTER FOR HARMONIZATION OF HUMAN RIGHTS AND INTELLECTUAL PROPERTY RIGHTS OF THE RESEARCH INSTITUTE OF INTELLECTUAL PROPERTY, \\ THE NATIONAL ACADEMY OF LAW SCIENCES OF UKRAINE, KYIV, UKRAINE \\ ${ }^{3}$ VOLODYMYR SHCHYHOL'S LAW FIRM, BROVARY, UKRAINE
}

\begin{abstract}
The aim: To propose effective jurisdictional methods in the field of legal regulation of surrogacy and ensuring the rights of surrogate mothers in the EU. Materials and methods: The research is based on international documents in the field of surrogacy, Ukrainian legislation, decisions of the European Court of Human Rights, scientists' works in the field of legal regulation of surrogacy, etc. General scientific methods (synthesis, induction, system method) and specific scientific methods (comparative legal and special legal methods) are used.

Conclusions: The study found that today some issues related to the surrogacy legal nature, conditions and procedure for its implementation remain out of the EU's attention. It is established that the adoption of a separate regional (within the EU) legal act will fully solve the existing problems, ensuring the effectiveness and transparency of surrogacy, will unify the medical tourism's mechanisms in the field of surrogacy. The authors have developed and proposed to enshrine the main provisions on surrogacy in the EU Regulation / Directive.
\end{abstract}

KEY WORDS: assisted reproductive technologies, human rights, surrogacy, surrogate mothers' rights

Wiad Lek. 2020;73(12 p. II):2871-2876

\section{INTRODUCTION}

Today both altruistic and commercial surrogacy are allowed in a few European countries. The countries in which it is permitted are extremely attractive to: 1) foreigners who, avoiding the relevant prohibitions at the level of their national legislation, come to these countries for the purpose of applying the surrogacy procedure; 2) foreign corporations that carry out professional activities in this area and resort to cross-border reproductive services. Citizens of Ukraine also actively use the opportunities of surrogacy. However, a quantity of important issues related to the using of surrogacy in the European Union remain unresolved; regulatory support of the rights of surrogate mothers seems to be avowedly imperfect and is not accompanied by sufficient legal guarantees. It creates a need to study relevant international documents in this area in order to develop and implement certain legal innovations for states that use surrogacy.

\section{THE AIM}

The aim of this article is to review current issues in the field of legal regulation of surrogacy and ensuring the rights of surrogate mothers in the EU, as well as to identify optimal ways to solve existing problems.

\section{MATERIALS AND METHODS}

As an empirical basis, the research is based on international documents in the field of surrogacy, Ukrainian legislation, decisions of the European Court of Human Rights, the work of scientists in the field of legal regulation of surrogacy, and so on. General scientific methods (synthesis, induction, system method) and specific scientific methods (comparative legal and special legal methods) are used.

\section{REVIEW AND DISCUSSION}

The possibilities of modern medicine have created a qualitatively new legal paradigm - human reproductive law. As can be seen from the report of the Committee on Social Affairs, Health and Sustainable Development of the Parliamentary Assembly of the Council of Europe (rapporteur - Petra De Sutter) "Anonymous donation of sperm and oocytes: balancing the rights of parents, donors and children" of 20 February 2019, as a result of the use of assisted reproductive technologies, more than eight million children have been born worldwide today [1] and this number is growing steadily.

One of the types of assisted reproductive technologies is surrogacy, which is used in Ukraine according to a special procedure approved by the Order of the Ministry of Health 
of Ukraine № 787 of September 9, 2013 [2] and in some foreign countries. At the same time, there are significant differences in legal regulation in the current legislation of many European countries, which gives rise to a number of discussions among scholars, legal practitioners, physicians and other social groups. Therefore, the legal nature of this phenomenon, its essence and purpose remain unclear, and legal regulation at the supranational regional level within the European Union needs to be detailed.

Thus, according to Baiborosha N.S., there are only a few legal documents in this area in the European Union: the Principles of 1989, the Explanatory Report to the Principles of 1989, the Convention for the Protection of Human Rights and Dignity in connection with the application of biology and medicine: 1997 Convention on Human Rights and Biomedicine and 1997 Explanatory Report to the Convention on Human Rights and Biomedicine. All the above documents, with the exception of the Convention, are of a recommendatory nature [3].

Some scientists suggest treating surrogacy as the fertilization of a genetically foreign woman (without using of her biological material) by implanting or transplanting an embryo using the genetic material of a male and a female who are married for the purpose of bearing and giving birth from the spouses, on the basis of relevant agreement between the spouses and the surrogate mother $[4, \mathrm{p} .43 ; 5$, p. 72]. However, this approach is quite debatable. There is currently no consensus among scholars on this issue. It is worth noting that we also do not share the above definition and consider it somewhat outdated, narrow. We believe that all methods of assisted reproductive technologies, including surrogacy, are methods of treatment, and therefore the possibility of their use can in no way depend on a person's social status, in particular, gender self-identification, marriage or same-sex partnership.

According to Lawrence Lvoff, there is a definition of surrogacy in 9 countries of the European Union. The law regulates pregnancy with the help of a third party, intention to give a child, agreement before the pregnancy, refusal of adoption, reference to the genetic link, reference to "agreement" / agreement [6] Of course, there are gaps in legal regulation that create a number of barriers for homosexuals, single people who for one reason or another are not married, people living in the same family without marriage registration, and violations of the rights of women who intend to become surrogate mothers (significantly limiting them) in the specified opportunity).

In this context, it should be emphasized that throughout the world, regardless of nationality and citizenship, the right to paternity has two dimensions - social and physiological. In the social dimension, it is possible to exercise the right to parenthood through appropriate social institutions. At the same time, in physiological dimension, this right follows from the very nature of man - the right to have a child arises from birth, and a person can exercise this right by reaching the appropriate level of physical maturity and emotional development. It is worth noting that the right to parenthood, even in the physiological dimension, is much broader than the physiological readiness and ability to conceive a child.

Both social and physiological components are markers of human health. Thus, the inability to conceive naturally due to physical or psychological characteristics should be considered as a health disorder with the obligation of the state to provide appropriate medical care and ensure the right to reproduce with all available resources of modern medical science. It is noteworthy that in 1987 the World Medical Association (WMA) adopted a Regulation on in vitro fertilization and embryo transplantation, which defines in vitro fertilization and embryo transplantation as a medical method of infertility treatment available in many parts of the world [7]. Note that the MMA clearly defines surrogacy as a method of treatment

Given this, we hold the position that access to treatment including surrogacy, should not be limited under any circumstances other than medical contraindications (for example, the presence of socially dangerous mental illness or hereditary diseases). In addition, homosexuality is recognized as the norm and is absent in the latest editions of the International Classification of Diseases [8] (in terms of the right to treatment by surrogacy by same-sex partners).

Moreover, the term "health" covers not only the physical but also mental and social well-being of a person, which is directly consistent with the position of the World Health Organization (hereinafter - WHO) [9]. At the same time, social well-being, among other determinants, presupposes the ability of people to conceive and give birth to children. In turn, the WHO Statute (Constitution) states that everyone has the right to the highest attainable standard of health, regardless of their social status. [9]. It follows that surrogacy, as a treatment method, should be available to everyone, without exception, who for some physiological or psychological reason can not have children, and not only to those who are married.

Consequently, depriving unmarried persons of the right to use the surrogacy procedure is not in line with generally accepted international standards and poses a serious threat to all countries where surrogacy is permitted. This also creates significant obstacles for people who come to other countries, including continental Europe, through medical tourism, in order to use the surrogacy procedure.

This state of affairs is also explained by the fact that modern democratic society has only recently taken on obligation to tolerate a person's infertility or other grounds that make it impossible to have genetically related children, as well as to refrain from stigmatizing such a person. At the same time, historically, the topic of infertility has always been taboo, and infertile people, especially women, have often been stigmatized [10, p. 163]. It is difficult to believe that such a stigma still exists in certain societies and is strangely superimposed on stigmatization of a surrogate mother, assisted gestation as a treatment method, and on a child [11, p. 48].

However, this state of affairs is unacceptable. In our view, all countries where surrogacy is permitted should create regulations that would allow every person (including a foreigner), regardless of their marriage, including same-sex 
partnerships, to use surrogacy as a treatment method. For example, from January 1,2019, this practice is successfully used in Washington State (United States) [12].

In addition, it should be noted that surrogacy and its integral component - assisted gestation - are always used in combination with other methods of assisted reproductive technologies. However, surrogacy is burdened by legal uncertainty and imperfection of its other necessary components (taking donor material, instrumental fertilization, etc.) that precede auxiliary gestation.

Summarizing, we must state that currently in Ukraine and in many countries around the world the following issues are unresolved: the number of oocytes from one donor that can be used by a medical institution; amount of sperm from one donor (from one dose) that can be used by a medical institution to one recipient; state monitoring of gamete donations' amount (especially important for female donation); control of the amount of donor material during women's donation; mandatory selection of blood group of donor and recipient; sexual selection of embryos to select the child sex.

However, the most systemic and conceptual shortcomings that significantly affect medical tourism and the person's rights to motherhood and fatherhood are the following: lack of regulation of surrogacy at the level of separate (special) international legal act that would prevent conflicts of private international law regarding surrogacy; lack of a clear unified form of contract for the provision of surrogacy services; uncertainty of the list of the rights of the surrogate mother's child during participation in the program of assisted reproductive technologies (in this case the experience of Great Britain is positive); violation of the woman's rights (future genetic mother) in the absence of registered marriage or homosexual sexuality with the use of assisted reproductive technologies; problems of relationship between medical secrecy, the right to secrecy about the state of parents' health and the child's right to information about their origin (non-medical aspect); stigmatization of surrogate mothers and committing criminal offenses against them in some cases; insufficient number and / or ineffectiveness of supranational legal remedies for the rights of surrogate mothers within the framework of criminal proceedings.

Thus, surrogacy is a separate set of medical, ethical and legal issues that are inextricably linked to other methods of assisted reproductive technologies and are a transnational problem of lack of legal regulation. To confirm this thesis, we note the following.

Along with this, as rightly noted by I.V. Chekhov, there is currently no regulation of the commercial program of surrogacy, which can lead to the transformation of the child and the surrogate mother into a "commodity" [13, p. 59]. Indeed, in the modern world there is an active demedecalization of surrogacy, a vision of a market service, which involves the use of appropriate manipulations to attract a third person - a surrogate mother (gestational courier). This is a significant problem for the development of medicine, as well as public order in many countries.
Ferraretti A.P., Pennings G., Gianaroli L. and other scientists rightly point out that in some cases, due to the relevant legal prohibitions in their countries of residence, but wanting to take advantage of surrogacy, always resort to cross-border reproductive services [14, p. 262]. Having the necessary amount of money, they migrate to other countries, where the use of assisted reproductive services, including commercial surrogacy, is allowed at the legislative level, primarily to Ukraine. Thus, in the Resolution of the European Parliament (hereinafter - the Parliament) of December 17, 2015 "On the Annual Report on Human Rights and Democracy in the World 2014 and the European Union's policy on the matter" Parliament condemned the practice (ed. - commercial) surrogacy, which undermines a woman's human dignity because her body and its reproductive functions are used as a commodity; pointed out that the practice of gestational surrogacy, which involves the reproductive exploitation and use of the human body for financial or other gain, particularly in cases of vulnerability of women in developing countries, should be banned and immediately addressed in human rights instruments [15]. A similar position is reflected in the report of the Committee on Social Affairs, Health and Sustainable Development of the Parliamentary Assembly of the Council of Europe (rapporteur: Petra De Sutter) "Children's rights related to surrogacy" of 23 September 2016 [16].

However, according to L. van Zyl and R. Walker, it is impractical to prohibit all forms of commercial surrogacy. Researchers are proposing to introduce a model that would motivate surrogate mothers to provide their services for appropriate compensation. At the same time, there should be a professional regulatory body that would oversee the selection of surrogate mothers, their training and compliance with ethical standards. This body would ensure fair payment, information of the parties about their rights and obligations, voluntary consent and legality of contractual restrictions concerning the surrogate mother. L. van $\mathrm{Zyl}$ and R. Walker believe that in this way the exploitation and unreasonable demands of future parents would be eliminated, minimizing the risk of harm [17]. We share this approach and believe that commercial surrogacy deserves to exist but should be regulated by an appropriate program that would clearly define the procedure, conditions and grounds for its implementation.

Undoubtedly, the realities of legal regulation in the field of surrogacy are far from ideal, as they are based on numerous anachronisms (are outdated) and do not correspond to the current level of society development. At the same time, for example, Ukrainian legislation in the field of reproductive medicine is considered the most liberal in Europe. This attracts foreigners to Ukraine (who are the main consumers of surrogacy services) and specialized foreign corporations. However, liberalism should not mean uncontrolled use of assisted reproductive technologies, including surrogacy. In view of this, we consistently defend the position on need to regulate these relations at the level of a special (separate) legal act - the Law of Ukraine "On Surrogacy", which would be based on a "model" international and designed to solve all 
or at least most existing problems in the specified plane. A similar novel could be useful for Greece (where surrogacy is used quite actively) and other countries.

In addition, we are convinced that States in which surrogacy is prohibited (France, Germany, Norway, Sweden, etc.) should review this issue at the level of national legislation, taking into account its medical aspect and the provisions of Article 8 of the Convention for the Protection of Human Rights and Fundamental Freedoms which enshrines the right of everyone to respect for their private and family life [18]. Of course, on the one hand, the European Court of Human Rights (for example, in Labassee v. France, application № 65941/11, judgment of 26 June 2014 [19] and in Mennesson v. France, application [ $65192 / 11$, decision of 26 June 2014 [20]) states that each state can decide on its own whether to allow or prohibit surrogacy within its territory. However, on the other hand, in the case of "S.H. and others v. Austria" (application no. 57813/00, judgment of 3 November 2011) the Court held that the couple's right to conceive a child and use artificial insemination for that purpose is protected by Article 8 of the Convention for the Protection of Human Rights and Fundamental Freedoms, as the decision is one of aspects of private and family life [21]. In turn, in the case of "Dickson v. the United Kingdom" (application № 44362/04, judgment of 04 December 2007) The European Court of Human Rights explicitly stated that the denial of access to artificial insemination to applicants in prison affected the applicants' right to privacy and family life, including the right to respect for their right to become genetic parents [22]. We believe that the unconditional recognition of surrogacy as an accessible method of treatment should become a universally recognized world practice.

In contrast, some international feminist organizations (such as The International Coalition for the Abolition of Surrogate Motherhood) oppose the legalization of surrogacy, [23] considering auxiliary gestation humiliating for the surrogate mother for some reason. However, as long as the world community's perception of surrogacy is in the grip of such speculation, existing problems will remain unresolved and hundreds of thousands of people will be deprived of the opportunity to make proper use of the institution of surrogacy.

The next problem is that quite often surrogate mothers, despite their high social mission, are stigmatized, "branded" (we have already mentioned above). This is primarily due to negative attitude of certain social groups to artificial insemination and assisted reproductive technologies in general. Moreover, in some cases, surrogate mothers are harassed or even victims of criminal offenses. Often surrogate mothers are left with their problems, not being able to effectively protect and / or restore their rights. All this indicates the imperfection of legislative mechanism for ensuring their rights, and especially the unified international mechanism, with elements of imperative to prohibit such harassment. It should be noted that in legislative world practice of any country today there is no criminal liability for bullying (harassment) of a surrogate mother, i.e. intentional systematic commission of physical, psychological or economic violence against her, which leads to physical or psychological suffering, health disorders, loss of ability to work or deterioration of the quality of victim's life.

In addition, as stated in paragraph 4 of the Declaration of Fundamental Principles of Justice for Victims of Crime and Abuse of Power, adopted by General Assembly resolution 40/34 of 29 November 1985, victims should be treated with compassion and dignity. They have the right to access justice mechanisms and compensation for damages as soon as possible in accordance with national law [24]. All this indicates the need to establish appropriate legislation regulating the participation of surrogate mothers who have suffered from criminal offenses in criminal proceedings.

Therefore, we believe that in criminal proceedings where the victims are surrogate mothers, the participation of a representative (professional lawyer) should be recognized as mandatory, because only then will they be able to exercise their rights properly, effectively and freely. In turn, we also emphasize the need to establish a proper procedure for persons who are surrogate mothers of free legal aid.

\section{CONCLUSIONS}

1. The study shows that today a number of issues related to legal nature of surrogacy, conditions and procedure for its implementation remain out of the EU's attention. Nevertheless, a perfect mechanism should be created for people who want to take advantage of this medical and legal institute. In our opinion, the adoption of a separate regional (within the EU) legal act will fully solve the existing problems, ensuring the effectiveness and transparency of surrogacy, will unify the mechanisms of medical tourism in the field of surrogacy.

2. We see a close position on the need to eliminate any discrimination in access to treatments such as in vitro fertilization and assisted gestation. Exceptions are only relevant medical contraindications (for example, the presence of socially dangerous mental illness or hereditary diseases).

3. Based on the provisions of Article 8 of the Convention for the Protection of Human Rights and Fundamental Freedoms, which enshrines the right of everyone to respect for their private and family life, the EU Regulation / Directive should lay down the basic provisions on surrogacy:

1) all methods of assisted reproductive technologies, including surrogacy, are methods of treatment;

2) possibility of applying such methods can in no way depend on a person's social status, in particular, gender self-identification, the fact of being married or having a same-sex partnership;

3) access to treatment: states are obliged to provide appropriate medical care and ensure the possibility of exercising the right to reproduction with all available resources of modern medical science;

4) restriction of access to treatment based on medical contraindications;

5) unification of the agreement form on provision of surrogacy services;

6) list of rights of all participants during participation in the program of assisted reproductive technologies; 
7) measures to prevent stigmatization of surrogate mothers and commission of criminal offenses against them in some cases;

8) creation of national professional regulatory bodies that would oversee the selection of surrogate mothers, their training and compliance with ethical standards with the development of standards for their activities;

9) ensuring the right of a representative (professional lawyer) to participate in criminal proceedings where the victims are surrogate mothers on a gratuitous basis.

\section{REFERENCES}

1. Report of Committee on Social Affairs, Health and Sustainable Development of Parliamentary Assembly of the Council of Europe (rapporteur: Ms Petra De Sutter), 20.02.2019. Anonymous donation of sperm and oocytes: balancing the rights of parents, donors and children. Available from: http://assembly.coe.int/nw/xml/XRef/XrefXML2HTML-en.asp?fileid=25439\&lang=en [reviewed 2020.08.20].

2. Poriadok zastosuvannia dopomizhnykh reproduktyvnykh tekhnolohii v Ukraini, zatverdzhenyi Nakazom Ministerstva okhorony zdorovia Ukrainy № 787 vid 09.09.2013 [The Order of the Ministry of Health Care of Ukraine No. 787 «On the Approval of the Procedure of Assisted Reproductive Technologies Application in Ukraine», adopted on 09.09.2013]. Available from: https://zakon.rada.gov.ua/laws/show/ z1697-13\#Text [reviewed 2020.08.20] (Ua).

3. Bajborosha N. S. Problemy surrogatnogo materinstva v prave Evropejskogo Sojuza [Problems of surrogacy in European Union law]. Nacional'naja gosudarstvennost' i evropejskie integracionnye processy . V 2 t . T . 2. Problemy unifikacii zakonodatel'stva v Sodruzhestve Nezavisimyh Gosudarstv i Evropejskom Sojuze:sb .nauch. tr. Minsk, 2008. Available from: https://elib.bsu.by/ bitstream/123456789/33378/1/034.pdf [reviewed 2020.08.20] (Ru).

4. Talanov Y.Y. Surohatne materynstvo: moralno-pravovi aspekty [Surrogacy: moral and legal aspects]. Scientific works collection of Kharkiv National Pedagogical University. 2012;19:42-47. (Ua).

5. Vatras V.A. Subiektnyi sklad pravovidnosyn shchodo implantatsii embriona dytyny zhintsi iz henetychnoho materialu podruzhzhia [Subject composition of legal relations regarding embryo implantation of parental genetic material to a woman]. Herald of Khmelnitsky Institute of Regional Management and Law. 2002;4;72-75. (Ua).

6. L'voff L. Surrogatnoe materinstvo. Vspomogatel'nye reproduktivnye tehnologii [Surrogacy. Assisted reproductive technologies]. Available from: https://rm.coe.int/168070b6d9 [reviewed 2020.08.20] (Ru).

7. WMA Statement on In-Vitro Fertilization and Embryo Transplantation. Available from: https://www.wma.net/policies-post/wma-statementon-in-vitro-fertilization-and-embryo-transplantation. [reviewed 2020.08.20]

8. Eleventh revision of the International Classification of Diseases (ICD-11). Available from: https://www.who.int/classifications/icd/revision/en/. [reviewed 2020.08.20].

9. Constitution of the World Health Organization. Available from: https:// apps.who.int/gb/bd/pdf_files/BD_49th-en.pdf\#page $=7$ [reviewed 2020.08.20].

10. Serdiuk I. Drevo bez plodu: bezditnist i bezpliddia v suspilstvi hetmanshchyny (sproba sotsialno-istorychnoho doslidzhennia) [A tree without fruit: childlessness and infertility in Cossack Hetmanate society (social and historical research attempt)]. Almanac of social history. 2017;13-14:161-180. (Ua).
11. Zharovska I, Oliinyk P. Pytannia statusu «netradytsiinykh» ditei [lssues of «non-traditional» children status]. Herald of Lviv Polytechnic National University. 2019;22:46-50. (Ua).

12. Revised Code of Washington, Title 26, Chapter 26.26A. Uniform Parentage Act. Available from: https://app.leg.wa.gov/RCW/default. aspx?cite $=26.26 \mathrm{~A}$ [reviewed 2020.08.20].

13. Chekhovska I.V. Surohatne materynstvo: teoretyko-pravovi pidkhody do rozuminnia sutnosti [Surrogacy: theoretical and legal approaches to understanding its nature]. International legal herald: actual issues of modernity (theory and practice). 2017;2-3 (6-7):58-64. (Ua).

14. Ferraretti AP, Pennings $G$, Gianaroli $L$ et al. Cross-border reproductive care: a phenomenon expressing the controversial aspects of reproductive technologies. Reprod Biomed Online. 2010; Feb;20(2):261266. doi: 10.1016/j.rbmo.2009.11.009.

15. European Parliament resolution of 17 December 2015 on the Annual Report on Human Rights and Democracy in the World 2014 and the European Union's policy on the matter. Available from: https:// www.europarl.europa.eu/doceo/document/TA-8-2015-0470_ EN.html?redirect. [reviewed 2020.08.20].

16. Report of Committee on Social Affairs, Health and Sustainable Development of Parliamentary Assembly of the Council of Europe (rapporteur: Ms Petra De Sutter), 23.09.2016. Children's rights related to surrogacy. Available fromhttp://assembly.coe.int/nw/xml/XRef/XrefXML2HTML-en.asp?fileid=23015\&lang=en [reviewed 2020.08.20].

17. L. van Zyl, R. Walker. Surrogacy, Compensation, and Legal Parentage: Against the Adoption Model. Bioethical Inquiry. 2015. doi: 10.1007/ s11673-015-9646-4. Available from: https://www.academia. edu/14093349/Surrogacy_Compensation_and_Legal_Parentage_ Against_the_Adoption_Model [reviewed 2020.08.20].

18. Konventsiia pro zakhyst prav liudyny i osnovopolozhnykh svobod vid 04.11.1950 [Convention on the Protection of Human Rights and Fundamental Freedoms, 04.11.1950]. Available from: https://zakon. rada.gov.ua/laws/show/995_004\#Text [reviewed 2020.08.20] (Ua).

19. Case of Labassee v. France, application no. №65941/1, judgement of the European Court of Human Rights of 26 June 2014. Available from: http:// hudoc.echr.coe.int/eng?i=001-145180 [reviewed 2020.08.20] ( Fr).

20. Case of Mennesson v. France, application no. № 65192/11, judgement of the European Court of Human Rights of 26 June 2014. Available from: http://hudoc.echr.coe.int/eng?i=001-145179 [reviewed 2020.08.20] (Fr).

21. Case of S.H. and others v. Austria, application no. 57813/00, judgement of the European Court of Human Rights of 03 November 2011. Available from: http://hudoc.echr.coe.int/eng?i=001-107325 [reviewed 2020.08.20].

22. Case of Dickson v. the United Kingdom, application no. 44362/04, judgement of the European Court of Human Rights of 04 December 2007. Available from: http://hudoc.echr.coe.int/eng?i=001-83788 [reviewed 2020.08.20].

23. Feminists call to abolish surrogacy in Europe. Available from: https:// www.bioedge.org/bioethics/feminists-call-to-abolish-surrogacy-ineurope/13073 [reviewed 2020.08.20].

24. Declaration of Basic Principles of Justice for Victims of Crime and Abuse of Power of 29 November 1985. Available from: https://undocs.org/ en/A/RES/40/34.

\section{ORCID and contributionship:}

Oksana Kuchynska: 0000-0003-3464-4798 A, B, D, F

Oksana Kashyntseva: 0000-0002-2598-5614 ${ }^{A, B, D, E}$

Oleh Shchyhol: 0000-0001-8860-4463 ${ }^{B, D}$ 


\section{Conflict of interest:}

The Authors declare no conflict of interest.

\section{CORRESPONDING AUTHOR}

\section{Oksana Kuchynska}

Institute of Law of Taras Shevchenko

National University of Kyiv, Kyiv, Ukraine

tel: +380442393245

e-mail:2000_oksana@ukr.net

Received: 25.08 .2020

Accepted: 26.11 .2020

A - Work concept and design, B - Data collection and analysis, C - Responsibility for statistical analysis,

D-Writing the article, E-Critical review, $\mathbf{F}$ - Final approval of the article 